\title{
DNA microarray analysis reveals variability of accessory genes among isolates recovered during an MRSA outbreak
}

\author{
P Basset ${ }^{1 *}$, S Monecke ${ }^{2,3}$, D Blanc ${ }^{1}$ \\ From International Conference on Prevention \& Infection Control (ICPIC 2011) \\ Geneva, Switzerland. 29 June - 2 July 2011
}

\section{Introduction / objectives}

Although MRSA outbreaks might have significant consequences on patients and/or health care resources, few data are available about the microevolution of a strain during a single outbreak. In this study, our aim was to characterize the variability of accessory genes among isolates recovered during a local MRSA outbreak.

\section{Methods}

Ten MRSA isolates recovered during a large outbreak occurring at the Lausanne University Hospital (Switzerland) were characterized using a DNA microarray (StaphyType, Alere Technologies, Germany) that targets approximately 180 genes including several resistance and virulence genes. Each isolate belonged to the South German clone (ST-228-SCCmec I) and had been recovered between September 2008 and December 2009.

\section{Results}

As expected during the clonal dissemination of a strain, the 10 isolates shared identical presence/absence for most of the c.a. 180 genes tested. Nevertheless, variation was observed for several resistance and virulence genes. These included the beta lactamase operon genes (blaZ, blaI, blaR), genes involved in the resistance to Trimethoprim and Mupirocin ( $d f r A$ and $m u p R$, respectively), a gene encoding unspecific efflux pump conferring resistance to a variety of antiseptic such as chlorhexidine ( $q a c A)$, and genes potentially involved in virulence (lukX, lukY,aur). This variability affected at least 5 of the ten isolates.

Hospital preventive medicine, Centre Hospitalier Universitaire Vaudois, Lausanne, Switzerland

Full list of author information is available at the end of the article

\section{Conclusion}

Our results indicate the gain/loss of resistance and virulence genes during a local outbreak, suggesting that the biological characteristics of the strain might vary through time.

\section{Disclosure of interest \\ None declared.}

\section{Author details}

${ }^{1}$ Hospital preventive medicine, Centre Hospitalier Universitaire Vaudois, Lausanne, Switzerland. ${ }^{2}$ Institute for Medical Microbiology and Hygiene, Dresden University of Technology, Dresden, Germany. ${ }^{3}$ Alere Technology, Jena, Germany.

Published: 29 June 2011

doi:10.1186/1753-6561-5-S6-P178

Cite this article as: Basset et al:: DNA microarray analysis reveals variability of accessory genes among isolates recovered during an MRSA outbreak. BMC Proceedings 2011 5(Suppl 6):P178.

Submit your next manuscript to BioMed Central and take full advantage of:

- Convenient online submission

- Thorough peer review

- No space constraints or color figure charges

- Immediate publication on acceptance

- Inclusion in PubMed, CAS, Scopus and Google Scholar

- Research which is freely available for redistribution

\section{Biomed Central}

(c) 2011 Basset et al; licensee BioMed Central Ltd. This is an open access article distributed under the terms of the Creative Commons Attribution License (http://creativecommons.org/licenses/by/2.0), which permits unrestricted use, distribution, and reproduction in any medium, provided the original work is properly cited. 